\title{
A STATISTICAL SUMMARY OF DATA FROM THE U.S. GEOLOGICAL SURVEY'S NATIONAL WATER QUALITY NETWORKS
}

by Richard A. Smith and Richard B. Alexander

U.S. Geological Survey Open-File Report 83-533

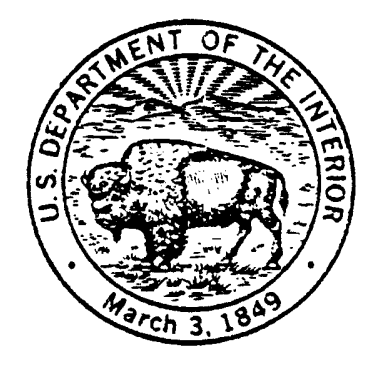


UNITED STATES DEPARTMENT OF THE INTERIOR

JAMES G. WATT, Secretary

GEOLOGICAL SURVEY

Dallas L. Peck, Director

For additional information write to:

Chief Hydrologist

U.S. Geological Survey

12201 Sunrise Valley Drive

Reston, Virginia 22092
Copies of this report can be purchased from:

Open-File Services Section Western Distribution Branch Box 25425, Federal Center Denver, Colorado 80225 (Telephone: (303) 234-5888) 
CONTENTS

\section{Page}

Abstract-1-1.1-1.-1

Introduction-1.1.

Statistical Methods-1.2 7

Data Screening-1-1

Estimates of Mean Concentration and Mean Transport of Common

Constituents -

Trend Test-1-1-10-10 8

Slope Estimator-10.1. 9

Flow Adjustment Test-_. 9

Summary Statistics for Trace Metals

References-1-10 30

TABLES

Table 1. Detection Limits (in units of ug L-1) applicable during the period of summary for total recoverable and dissolved metals

Table 2. Station list by drainage basin-14

Table 3. Station list by state-1.-1 21

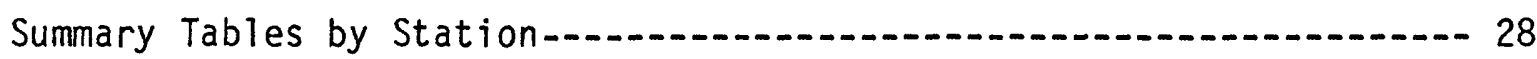


A STATISTICAL SUMMARY OF DATA FROM THE U.S. GEOLOGICAL SURVEY'S NATIONAL WATER QUALITY NETWORKS

By Richard A. Smith and Richard B. Alexander

\section{ABSTRACT}

The U.S. Geological Survey operates two nationwide networks to monitor water quality, the National Hydrologic Bench-Mark Network and the National Stream Quality Accounting Network (NASQAN). The Bench-Mark network is composed of 51 stations in small drainage basins which are as close as possible to their natural state, with no human influence and little likelihood of future development. Stations in the NASQAN program are located to monitor flow from accounting units (subregional drainage basins) which collectively encompass the entire land surface of the nation. Data collected at both networks include streamflow, concentrations of major inorganic constituents, nutrients, and trace metals.

The goals of the two water-quality sampling programs include the determination of mean constituent concentrations and transport rates as well as the analysis of long-term trends in those variables. This report presents a station-by-station statistical summary of data from the two networks for the period 1974 through 1981. 


\section{INTRODUCTION}

The U.S. Geological Survey operates two large networks to monitor water quality in surface waters, the National Hydrologic Bench-Mark Network and the National Stream Quality Accounting Network (NASQAN). Both are nationwide programs for collection and analysis of similar constituents, but were designed with different objectives, as described briefly below. The purpose of this report is to present a station-by-station statistical summary of data collected over a 7-year period from the Bench-Mark and NASQAN networks. Included in the summary are data from stations in operation as of October 1976--a total of 51 Bench-Mark stations and 313 NASQAN stations. The period of summary begins October 1974 (except for 22 NASQAN stations established between that date and October 1976) and ends October 1981.

Hydrologic Bench-Mark stations are located in small drainage basins in a variety of climatic, hydrologic, geologic, and geographic settings. The basins are as close to the natural state as possible with little likelihood of future development within the basin. The need for a network of Bench-Mark stations was pointed out by Leopold (1962): "A recurring question of our times, and one that we anticipate will be increasingly vexing to posterity, is to know how much of the change in our environment is caused by man and how much is natural... changes must be measured relative to some standard base or datum."

Basin selection for the Bench-Mark program was based on the following criteria (Cobb and Biesecker, 1971):

1. No manmade storage, regulation, or diversion currently exists or is probable for many years.

2. Ground water within the basin will not be affected by pumping from wells.

3. Conditions are favorable for accurate measurement of streamflow, chemical and physical quality of water, ground-water conditions, and the various characteristics of weather, principally precipitation.

4. The probability is small of special natural changes due to such things as major activities of beavers, overgrazing or overbrowsing by game animals, or extensive fires.

As originally proposed by Langbein and Hoyt (1959, p.18) and Leopold (1962), the network was to have comprised 100 stations. It has been very difficult to find basins which meet the above criteria and at present, only 51 sites are included in the water-quality component of the Bench-Mark program. The sites are well distributed throughout the United States and represent most of the physiographic divisions described by Fenneman (1928). Natural environments are well represented by the network since elevations within the different basins range from $100 \mathrm{ft} .(30 \mathrm{~m})$ to over $14,000 \mathrm{ft} .(4,300 \mathrm{~m})$. Vegetation ranges from sparse desert growth to dense coniferous forests.

All of the basins monitored in the Bench-Mark network are relatively small. Thirty-nine of the 51 basins are less than $100 \mathrm{mi}^{2}\left(260 \mathrm{~km}^{2}\right)$ though only 4 are less than $10 \mathrm{mi}^{2}\left(26 \mathrm{~km}^{2}\right)$. The smallest basin, in New Jersey, is $2.31 \mathrm{mi}^{2}$ 
$\left(5.98 \mathrm{~km}^{2}\right)$ whereas the largest, in Alaska, is $2,006 \mathrm{mi}^{2}\left(5,196 \mathrm{~km}^{2}\right)$. A complete description of the sites compiled by Cobb and Biesecker (1971) includes location, drainage area, physiographic area, climate, topography, rock type, vegetation, manmade influences, gage location, flow characteristics, water quality, ground-water information, and availability of data.

For the period of time summarized in this report (see above), samples were collected monthly at 34 sites, bimonthly at 13 , and quarterly at 4 sites. Field measurements, including discharge, specific conductance, dissolved oxygen, temperature, $\mathrm{pH}$, bacteria, suspended sediment, and common ions are run at every visit to the station. Two samples per year are collected for trace metals.

The National Stream Quality Accounting Network was established in 1972 to provide data of the type needed to determine large-scale, long-term trends in the physical, chemical, and biological characteristics of the Nation's surface waters. NASQAN stations are located predominantly on large rivers to measure both quantity and quality of water moving within and from a system of drainage basins called "accounting units."

The Water Resources Planning Act of 1965 (PL 89-80) established the Water Resources Council (WRC) to facilitate coordination of water-resource and landresource activities. The WRC divided the United States into 21 regions and 220 subregions. The Geological Survey further subdivided the regions and subregions into approximately 350 accounting units. Operational guidelines for NASQAN specify that an attempt will be made to measure water discharge and quality for at least 90 percent of the surface water leaving an accounting unit (Ficke and Hawkinson, 1975). This means that almost all NASQAN stations are located at the downstream end of accounting units and for inland accounting units especially, stations are generally located on large rivers.

Meeting the 90 percent goal on inland accounting units is relatively easy. In coastal accounting units, however, the numerous small streams with parallel drainage present problems. To meet the goal of measuring quantity and quality of 90 percent of the water leaving the coastal unit, a very large number of stations would have to be estalished, some on very small streams. To avoid the prohibitive cost and personnel requirements, the measurement goal of the network has been reduced to 30-50 percent for coastal units.

For the period summarized in this report, NASQAN samples were collected on a monthly basis. Water-quality characteristics that are measured at NASQAN stations include field measurements of temperature, $\mathrm{pH}$, specific conductance, dissolved oxygen, major inorganic ions, major nutrients, organic carbon, bacteria and phytoplankton counts, and suspended sediment. Additional samples are collected approximately quarterly for determination of trace elements.

Laboratory methods used in analyzing samples from both networks are described in detail in Skougstad, et. al. (1979). Data collected from the networks are available in machine readable format from the Survey's WATSTORE computer storage and retrieval system (Hutchison, and others, 1975). All data are also published in the series, "Water Resources Data for (state), Water Year (year)," an annual report prepared on a state-by-state basis. 


\section{STATISTICAL METHODS}

\section{Data Screening}

An effort was made to eliminate obvious typographical or recording errors in the data base by discarding any negative values or values exceeding five standard deviations of the mean for the period of summary. For certain common constituents having highly skewed frequency distributions (nitrate-nitrite, ammonia, total organic carbon, phosphorus, suspended sediment, turbidity, fecal coliform, fecal streptococci, and phytoplankton), this criteria was applied to the logrithmic transformations of the data. Also, pH values exceeding 14 and temperature values exceeding $45^{\circ} \mathrm{C}$ were discarded.

Multiple concentration values sometimes appear in the records of national network stations during a single sampling period (e.g., month, quarter, etc.) due to the use of these stations in other water quality investigations. In order to maintain an even frequency of observation, only the first concentration-stream flow data pair for each sampling period was used in preparing the statistical summary. In cases where instantaneous streamfiow values were unavailable, the first value of concentration occurring during a sampling period was selected.

\section{Estimates of Mean Concentration and Mean Transport of Common Constituents}

Mean concentration values for the period of summary are estimated as sample averages and are expressed as $\mathrm{mg} \mathrm{L-T}$ for all constituents except: $\mathrm{pH}$ (standard units), conductivity (umhos $\mathrm{cm}^{-1}$ ), turbidity (JTU), fecal coliform (colonies $100 \mathrm{mi}^{-1}$ ), fecal streptococci (colonies $10 \mathrm{ml}^{-1}$ ), phytoplankton (cells $\mathrm{ml}^{-1}$ ).

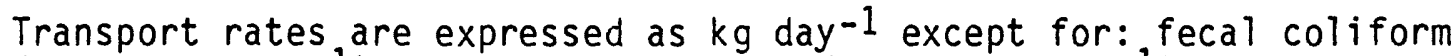
(colonies day ${ }^{-1}$ ), fecal streptococci (colonies day ${ }^{-1}$ ), and phytoplankton (cells day -1$)$.

NASQAN and Bench-Mark sites are sampled at fixed-time intervals without consideration for the variability in streamflow. As a result, estimates of annual transport derived by averaging the sample measurements of transport (product of discharge and concentration) may not accurately represent the total amount of material carried by the stream during the course of a year. Extremely high flows, which may carry disproportionately large amounts of material, are frequently missed in the fixed-sampling schedule employed at NASQAN stations. In such cases, the integration of the transport-discharge relationship (rating curve) over the daily flow-frequency distribution may provide a more accurate estimate of mean transport.

A flow-frequency distribution was computed for each station by separating the distribution of daily flows into $34 \mathrm{classes}$ (see Hutchinson, and others, 1975; see also Searcy, 1959). The flow classes were based on a logarithmic scale such that the class width becomes increasingly larger as the magnitude of flow increases. The midpoint of each class was supplied to the appropriate equation describing the relationship between flow and transport to produce 34 values of transport which were weighted by the probability of their respective classes and summed to obtain a mean rate of transport. 
The relationship between transport and discharge was described in linear terms by performing a least squares regression on the log transformations of the monthly, bimonthly, or quarterly samples of transport and discharge. The regression equation can be expressed as

$$
Y=a+b X+e
$$

where $Y=\ln T, X=\ln Q$, e $N\left(0, S^{2}\right), T$ is transport, $Q$ is discharge, $S$ is the regression standard error, and $a$ and $b$ are regression estimates of the intercept and slope, respectively.

Estimates of the conditional mean and variance of $Y$ for each of the 34 values of $Q$ were substituted into an equation which relates the expected value of lognormally distributed random variables to the mean and variance of the normally distributed logarithms (Aitchson and Brown, 1963; Heien, 1968) to determine estimates of transport for each flow class. Estimates of transport rate for each of the 34 classes were determined from the equation $E[T \mid Q]=\exp \left(a+b \ln Q+1 / 2 S^{2}\right)$ (Heien, 1968, p. 1034), where $E[T \mid Q]$ is the expected value of transport conditioned on discharge. The mean transport rate is then computed as the weighted sum of the $34 E[T \mid Q]$ values.

In cases where the relationship between transport and discharge is weak, a simple average of the historical monthly, bimonthly, or quarterly records of transport may provide the most accurate estimate of the mean rate of transport. Mean transport rates computed as simple averages of the historical records and mean transport rates obtained through the flow-frequency integration technique described above were determined for a 11 NASQAN and Bench-Mark sites having at least 16 pairs of concentration and discharge values and compared on the basis of their respective estimated standard error. The transport estimate having the lower standard error was selected for use in the tables. Estimated standard errors were calculated on the basis of estimated values of $b, s$, variance of $x$, and sample size under the assumption that transport and discharge are distributed bivariate lognormal (Gilroy, E. J., and Hirsch, R. M., written communication).

For those stations with incomplete records of daily flow (records beginning after 1975 or ending prior to 1981) a simple average of monthly, bimonthly, or quarterly values of transport was computed. Such cases are denoted in the tables with an "a." Estimates of the mean transport rate were not computed for constituents with fewer than 16 values of concentration and discharge. These cases are denoted in the tables by an "I.D." (insufficient data) symbol.

\section{Trend Test}

The Seasonal Kendali test for trend (Hirsch, et. al., 1982) was applied to the concentration and transport records of 22 common constituents and to the concentration records of 16 trace metals (see tables for complete list of chemical constituents). The Seasonal Kendall test is designed for the analysis of time trend in seasonally varying water-quality data from fixed, regularly- 
sampled monitoring sites such as those included in the national networks. The procedure includes an estimate of the median rate of change in the constituent over the sampling period (trend slope) and a method for flow-adjusting the concentration values to remove much of the variation in water quality which is the result of variations in streamflow (see below). Trend is defined as monotonic change with time, occurring either as an abrupt or gradual change in water quality.

At least 24 values of concentration or transport for monthly and bimonthly sampled constituents and 16 for quarterly sampled constituents were required before the Seasonal Kendall test was performed. In conducting the trend test for the monthly sampled constituents, each month was defined as a "season." Six seasons (Dec.-Jan., Feb.-March...) were defined for bimonthly sampled constituents, four seasons (Dec.-Feb., March-May....) were defined for quarterly sampled constituents, and two seasons (Dec.-May, June-Nov.) were defined for biannually sampled constituents. Records having fewer than the required number of values are identified in the tables by an "I.D." symbol. The level of statistical significance of the test is reported in the tables as $p$, the probability of error in rejecting the null hypothesis, where the null hypothesis is that no monotonic trend exists in the data. Values of $\mathrm{p}$ less than 0.01 are denoted by an "H" (highly significant) and values of $p$ less than 0.05 are denoted by an "S" (significant).

\section{Slope Estimator}

Trend slope is the estimated rate of change in a constituent (concentration or transport) and is expressed in units of percent of the mean per year. Trend slope estimates are reported for all constituents regardless of the significance level of the trend test.

\section{Flow Adjusted Trend Test}

Stream discharge is often related to the concentration of a water-quality constituent. Substances which are introduced to the stream as a component of the runoff, such as suspended sediment, may show a positive sloping relationship to flow, whereas certain chemical constituents which have a relatively constant source within the basin may become diluted with increasing flow and show a negative relationship to discharge. The relationship between concentration and discharge may even exhibit both positive and negative responses over a range of flows. Consequently, trends resulting from changes in the mechanisms affecting the rate of input of constituents to the stream may be difficult to identify because of the degree of influence exerted by variations in flow.

An adjustment for these flow-related effects was accomplished by estimating the relationship between concentration and discharge through a least squares regression, and then applying the Seasonal Kendall trend test to the regression residuals (differences between actual and estimated concentrations). 
One of two general models were used to describe the relationship between concentration and discharge depending on the constituent to be tested. The first, a linear model, was applied to the following constituents: temperature, $\mathrm{pH}$, alkalinity, sulfate, calcium, magnesium, sodium, potassium, chloride, silica, dissolved solids, specific conductivity, and dissolved oxygen.

The linear model has the general form

$$
C=a+b f(Q)
$$

where $C$ is the estimated concentration, $Q$ is the instantaneous discharge, and $f(Q)$ may have one of the following four specific functional forms:

$$
\begin{aligned}
& f(Q)=Q \quad \text { linear } \\
& f(Q)=\ln Q \quad \log \\
& f(Q)=1 /(1+B Q) \text { hyperbolic } \\
& f(Q)=1 / Q \quad \text { inverse }
\end{aligned}
$$

These four functions and the method for selecting an appropriate B coefficient are described in Smith, et. al. (1982). Regressions were performed using each of the four functions and the one having the highest $r$-squared value (shown in the tables) was selected for use in the flow adjustment procedure and is shown in the tables as "lin," "log," "hyp," or "inv," respectively. The slope of the relationship between concentration and discharge is given in the tables as "+" (positive) or "-" (negative). The letter " $\mathrm{H}$ " or "S" appears next to each $r$-squared value that is statistically significant at the 0.01 or 0.05 level, respectively. The number of concentration-discharge pairs used in the regression is shown in the tables in the column headed "N."

The second model used to describe the relationship between concentration and discharge was a nonlinear or exponential model (denoted in the tables as "exp") of the form

$$
c=b_{0}+b_{1} \ln Q+b_{2}(\ln Q)^{2}
$$

where $C$ is the estimated concentration, $Q$ is the instantaneous discharge, and InQ is the natural logarithm of discharge. Investigations of the statistical properties of the 22 common constituents at NASQAN sites (R. M. Hirsch, written communication) indicate that this model most appropriately describes the relationship between concentration and discharge for the following constituents: nitrate-nitrite, ammonia, total organic carbon, phosphorous, suspended sediment, turbidity, fecal coliform, fecal streptococci, and phytoplankton. The sign of the slope of the concentration-discnarge relationship for the above constituents was determined at the median flow. 
Summary Statistics for Trace Metals

Summary statistics for trace metals are presented in two sections in the tables, one for dissolved forms and the second for total recoverable forms. Trace metal concentrations are expressed as ug $L^{-1}$, and transport rates are expressed as $\mathrm{kg}$ day -1 .

The concentrations of trace metals at many NASQAN and Bench-Mark stations are often too low to be adequately detected by present analytical methods. The statistical uncertainty associated with these extremely low concentrations is usually considered to be unacceptably large, and as a result, these values are "flagged" in the record as being less than or equal to an acceptable detection limit. The measured concentration of a flagged value, therefore, is unknown but lies in the range from zero to the detection limit.

The analytical procedures for certain metal constituents have undergone improvements during the period of summary resulting in the use of lower detection limits during the latter portion of the record. Table 1 shows the detection limits that were applied to both dissolved and total recoverable metals during the period of summary. Only the highest of the detection limits used during the period of summary appear in the tables. The fraction of the concentration values in the record exceeding this higher detection limit is reported in the table in the column headed "frequency exceeded."

The median for the dissolved and total metal constituents is computed by assigning the value of the higher detection limit to values flagged in the record at either limit. If more than half the values are flagged, then the median is reported in the tables as less than or equal to the higher detection limit (<=D.L.).

Since flagged values in the record are associated with a range of possible values (from zero to the detection limit), minimum and maximum estimates of the mean concentration and transport rate are calculated and displayed separately in the tables. Minimum estimates assume a value of zero for concentrations reported as less than or equal to either of the laboratory detection limits, and maximum estimates assume that such flagged values are equal to the applicable detection limit. These maximum and minimum estimates of the mean should not be confused with the total range of concentrations occurring in the record.

At some stations, estimates of mean dissolved metal concentrations exceed the estimates of mean total metal concentrations. This may be accounted for by either missing values in the total or dissolved records, or by error in the analytical methods. In general, estimates of dissolved metal concentrations are considered more reliable. As a caution, a "*" appears in the tables next to the mean total concentrations that are less than the corresponding mean dissolved concentrations. 
The Seasonal Kendall test for trend is nonparametric and involves comparisons between the relative values or ranks of the data. The test is therefore very appropriate for the analysis of time trends in the concentrations of trace metals since the presence of flagged values in the record present no special problem in making relative comparisons between concentration values. For the purpose of trend testing, flagged values were set equal to the highest laboratory detection limit used during the period of record and were then treated the same as unflagged data. The highest detection limit thus becomes a lower bound on the applicability of the trend test. Sixteen values (eight for Bench-Mark sites), including at least one unflagged value, were considered sufficient to run the trend test. In cases where no unflagged values occur in the record, the tables show "N.D." (not detected).

The direction of change is reported in the tables in the column labeled "slope." The rate of change, however, is not computed due to the presence of flagged values in the record.

For records having at least six pairs of concentration and discharge values, mean estimates of transport for the period of summary were obtained as follows:

1. The frequency distribution of daily flows was separated into three intervals such that each class included at least two concentrationdischarge data pairs.

2. The estimated transport of each flow interval was calculated as the product of the average concentration and average daily flow of the interval. Summing transport over all flow intervals, after weighting for the probability of the interval, yields the mean transport rate. Minimum and maximum estimates of the mean transport rate were calculated by alternately assigning a value of zero, and the value of the detection limit, to flagged concentration values.

For stations with incomplete records of daily flows, the frequency distribution of instantaneous flows was used instead; such cases are denoted in the tables with an "a" before the transport rate. Estimates of the mean rate of transport were not calculated for records with fewer than six pairs of concentration and discharge values. These cases are denoted in the tables by an "I.D." symbol. 
Table 1.

Detection limits (in units of ug $L^{-1}$ ) applicable during the period of summary for total recoverable and dissolved metals.

Aluminum
Arsenic
Barium
Boron
Cadmium
Chromium
Copper
Iron
Lead
Manganese
Mercury
Nickel
Silver
Zinc

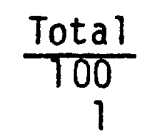

100

20

2,20

2,20

2,20

10

2,200

10

$0.1,0.5$

2,200

2, 20

2, 20
Dissolved

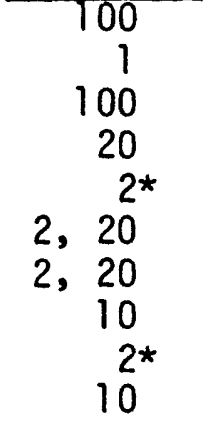

$0.1,0.5$

2, 200

$22^{*}$

*For dissolved cadmium, lead, and silver, only data based on the lower detection limits were used in this summary since fewer than one percent of the concentration values were analyzed using the higher detection limit. 
Table 2. Station list by drainage basin.

Station No. National Hydrologic Bench-Mark Stations

10542.00

13621.98

14665.00

15456.00

20388.50

21353.00

21973.00

22126.00

23271.00

24502.50

24791.55

32372.80

32767.00

34600.00

36040.00

40010.00

40637.00

50649.00

51244.80

53760.00

62882.00

63325.15

64090.00

66238.00

67759.00

68979.50

70607.10

70830.00

73112.00

$73357: 00$

73730.00

81039.00

83779.00

84317.00

93529.00

94306.00

95083.00

101722.00

102449.50

102493.00

112645.00

114755.60

114922.00

120393.00

124160.00

124473.90

130183.00

131695.00

133315.00

152927.00

167170.00
WILD RIVER AT GILEAD, ME

ESOPUS CREEK AT SHANDAKEN, NY

MCDONALDS B IN LEBANON STATE FOREST, NJ

YOUNG WOMANS CREEK NEAR RENOVO, PA.

HOLIDAY CREEK NEAR ANDERSONVILLE, VA.

SCAPE ORE SWAMP NEAR BISHOPVILLE, SC

UPPER THREE RUNS NEAR NEW ELLENTON, SC

FALLING CREEK NEAR JULIETTE, GA.

SOPCHOPPY RIVER NR SOPCHOPPY, FLA.

SIPSEY FORK NEAR GRAYSON, AL

CYPRESS CREEK NR JANICE, MS.

UPPER TWIN CREEK AT MCGAW, OH

SOUTH HOGAN CREEK NEAR DILLSBORO, IND.

CATALOOCHEE CREEK NEAR CATALOOCHEE, NC

BUFFALO RIVER NEAR FLAT WOODS, TENN.

WASHINGTON CREEK AT WINDIGO, MICH.

POPPLE RIVER NEAR FENCE, WI

BEAVER CREEK NR FINLEY, ND

KAWISHIWI RIVER NEAR ELY, MN

NORTH FORK WHITEWATER RIVER NEAR ELBA, MN

BEAUVAIS CREEK NEAR ST. XAVIER, MT.

BEAR DEN CREEK NR MANDAREE, ND

CASTLE CR ABOVE DEERF IELD RES NEAR HILL CITY, SD

ENCAMPMENT RIV AB HOG PARK CR NR ENCAMPMENT, WYO

DISMAL RIVER NR THEDFORD, NEBR

ELK CREEK NEAR DECATUR CITY, IOWA

NORTH SYLAMORE CREEK NEAR FIFTY SIX, ARK.

HALFMOON CREEK NEAR MALTA, CO.

BLUE BEAVER CREEK NR CACHE, OK

KIAMICHI RIVER NR BIG CEDAR, OK

BIG CREEK AT POLLOCK, LA

SOUTH FORK ROCKY CREEK NEAR BRIGGS, TEX.

RIO MORA NEAR TERRERO, NM

LIMPIA CREEK ABOVE FT DAVIS, TEX.

VALLECITO CREEK NEAR BAYFIELD, CO.

MOGOLLON CREEK NEAR CLIFF, NM

WET BOTTOM CREEK NR CHILDS, ARIZ.

RED BUTTE CREEK AT FT. DOUGLAS NR. SLC, UTAH

STEPTOE C NR ELY, NV

$S$ TWIN R NR ROUND MOUNTAIN, NV

MERCED R AT HAPPY ISLES BRIDGE NR YOSEMITE, CALIF

ELDER CREEK NEAR BRANSCOMB, CALIF

CRATER LAKE NEAR CRATER LAKE,OREG.

NORTH FORK QUINAULT R NEAR AMANDA PARK, WASH.

HAYDEN CK BELOW N FK, NR HAYDEN LAKE, IDAHO

ANDREWS CREEK NEAR MAZAMA, WASH.

CACHE CREEK NEAR JACKSON, WYO

BIG JACKS CREEK NEAR BRUNEAU, ID

MINAM RIVER AT MINAM,OREG.

TALKEETNA RIVER NEAR TALKEETNA AK

HONOLII STREAM NR PAPAIKOU HAWAII HI 
Station No. National Stream Quality Accounting Stations

10171.00

10210.50

10345.00

10594.00

10660.00

10965.50

11035.00

11550.50

11840.00

12055.00

13045.00

13580.00

14041.00

14085.00

14635.00

14745.00

14910.00

15405.00

15535.00

15705.00

16465.80

16730.00

20350.00

20495.00

20805.00

20835.00

20895.00

21057.69

21290.00

21320.00

21360.00

21705.00

21750.00

21765.00

21985.00

22025.00

22280.00

22310.00

22444.50

22480.00

22530.00

22730.00

22790.00

22886.00

22924.80

22967.50

23030.00

23130.00

23205.00

23290.00

23580.00

23590.00
AROOSTOOK RIVER AT CARIBOU, ME

ST. CROIX RIVER AT MILLTOWN, ME

PENOBSCOT RIVER AT WEST ENFIELD, ME

ANDROSCOGGIN RIVER AT BRUNSWICK, ME

SACO RIVER AT CORNISH, ME

MERRIMACK RIVER ABOVE LOWELL, MA

CHARLES RIVER AT DOVER, MA

CONNECTICUT RIVER AT WALPOLE, NH

CONNECTICUT R AT THOMPSONVILLE, CT

HOUSATONIC R AT STEVENSON, CT

PECONIC RIVER AT RIVERHEAD NY

HUDSON RIVER AT GREEN ISLAND NY

RARITAN R NR SOUTH BOUND BROOK NJ

TOMS R NR TOMS RIVER NJ

DELAWARE R AT TRENTON NJ

SCHUYLKILL RIVER AT PHILADELPHIA, PA.

CHOPTANK R NR GREENSBORO, MD

SUSQUEHANNA RIVER AT DANVILLE, PA.

WEST BRANCH SUSQUEHANNA RIVER AT LEWISBURG, PA.

SUSQUEHANNA RIVER AT HARRISBURG, PA.

POTOMAC R AT CHAIN BRIDGE, AT WASH, DC

PAMUNKEY RIVER NR HANOVER VA

JAMES RIVER AT CARTERSVILLE, VA

BLACKWATER R NR FRANKLIN, VA

ROANOKE RIVER AT ROANOKE RAPIDS, N.C.

TAR RIVER AT TARBORO, N. C.

NEUSE RIVER AT KINSTON, N. C.

CAPE FEAR R AT LOCK \# I NR KELLY, NC

PEE DEE R NR ROCKINGHAM, NC

LYNCHES RIVER AT EFFINGHAM S. C.

BLACK RIVER AT KINGSTREE, S.C.

LAKES M-M DIV CANAL NR PINEVILLE S. $C$.

EDISTO RIVER NR GIVHANS S.C.

COOSAWHATCHIE RIVER NR HAMPTON S.C.

SAVANNAH RIVER NEAR CLYO, GA

OGEECHEE RIVER NEAR EDEN, GA.

SATILLA RIVER AT ATKINSON, GA.

ST MARYS RIVER NR MACCLENNY, FLA.

ST. JOHNS RIVER AT PALATKA, FLA.

SPRUCE CREEK NR SAMSULA, FLA.

MAIN CANAL AT VERO BEACH, FLA.

KISSIMMEE R AT S-65E NR OKEECHOBEE, FLA.

WEST PALM BEACH CANAL AT WEST PALM BEACH FLA

MIAMI CANAL AT NW36 ST, MIAMI, FL

CALOOSAHATCHEE CANAL AT ORTONA LOCK NR LA BELLE

PEACE RIVER AT ARCADIA, FLA.

HILLSBOROUGH RIVER NR ZEPHYRHILLS, FLA.

WITHLACOOCHEE RIVER NR HOLDER, FLA.

SUWANNEE RIVER AT BRANFORD, FLA.

OCHLOCKONEE RIVER NR HAVANA, FLA.

APALACHICOLA RIVER AT CHATTAHOOCHEE FLA

CHIPOLA RIVER NR ALTHA, FLA. 


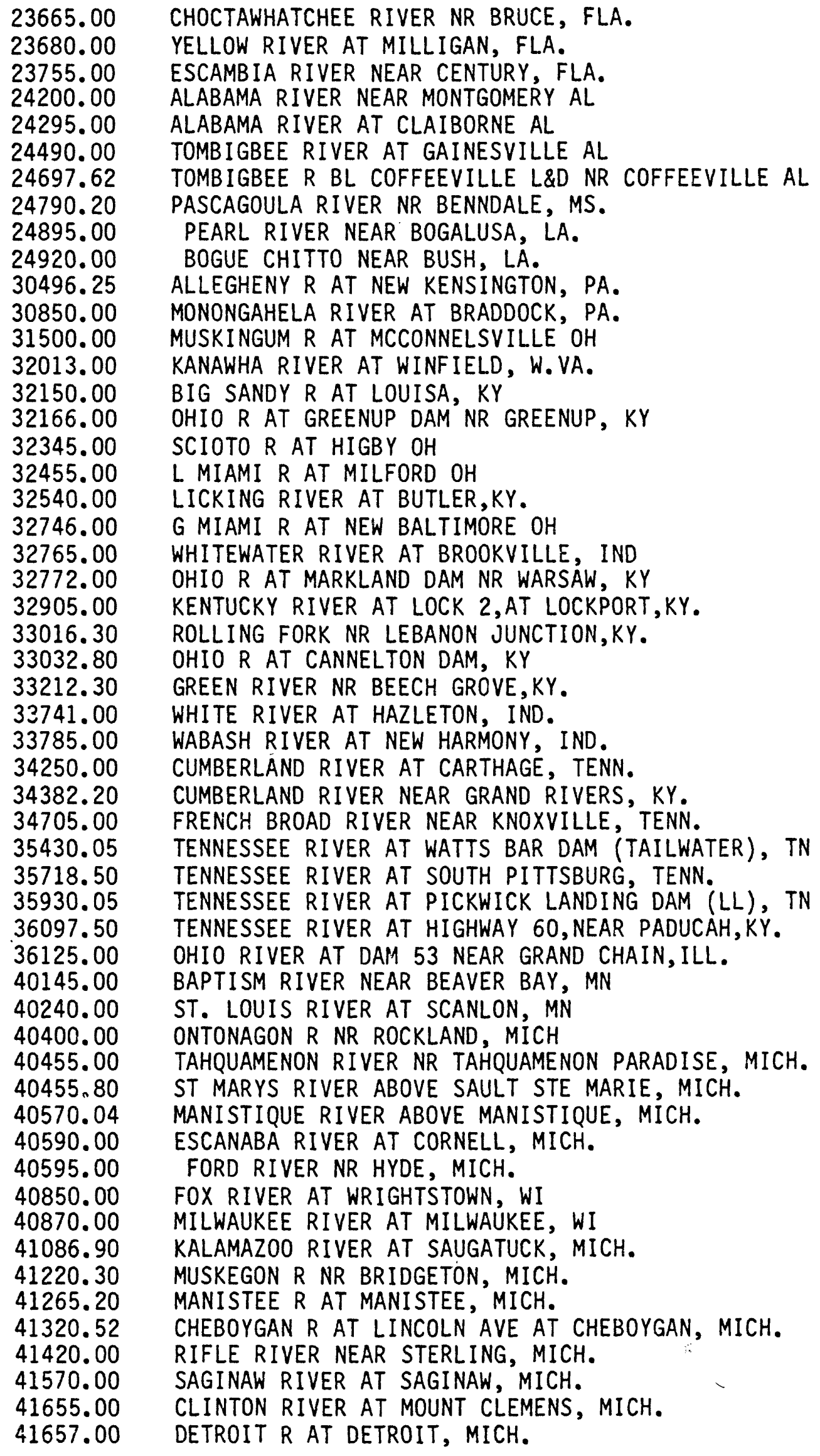


41935.00

42080.00

42196.40

42320.06

42490.00

42605.00

42643.31

42690.00

42950.00

51120.00

51240.00

51315.00

52670.00

53300.00

53405.00

53695.00

53785.00

54070.00

54205.00

54465.00

54745.00

54906.00

55435.00

55875.50

55941.00

55995.00

60545.00

61095.00

61305.00

61320.00

61745.00

61855.00

62145.00

62947.00

63085.00

63265.00

63295.00

63370.00

63384.90

63405.00

63540.00

63578.00

64380.00

64393.00

64400.00

64520.00

64530.00

64655.00

64785.00

64855.00

64860.00

66860.00

67640.00

67924.99
MAUMEE R AT WATERVILLE OH

CUYAHOGA R AT INDEPENDENCE OH

NIAGARA RIVER (LAKE ONTARIO) AT FORT NIAGARA NY

GENESEE RIVER(CHARLOTTE DOCKS)AT ROCHESTER NY

OSWEGO RIVER AT LOCK 7 AT OSWEGO NY

BLACK RIVER AT WATERTOWN, NY

ST LAWRENCE R AT CORNWALL ONT NR MASSENA, NY

ST REGIS RIVER AT BRASHER CENTER NY

RICHELIEU R (L CHAMPLAIN) AT ROUSES POINT NY

ROSEAU RIVER BELOW STATE DITCH 51 NR CARIBOU, MN

SOURIS RIVER NR WESTHOPE, ND

LITTLE FORK RIVER AT LITTLEFORK, MN

MISSISSIPPI RIVER NEAR ROYALTON, MN

MINNESOTA RIVER NEAR JORDAN, MN

ST. CROIX RIVER AT ST. CROIX FALLS, WI

CHIPPEWA RIVER AT DURAND, WI

MISSISSIPPI RIVER AT WINONA, MN

WISCONSIN RIVER AT MUSCODA, WI

MISSISSIPPI RIVER AT CLINTON, IOWA

ROCK RIVER NEAR JOSLIN, IL

MISSISSIPPI RIVER AT KEOKUK, IOWA

DES MOINES RIVER AT ST. FRANCISVILLE, MO.

ILLINOIS RIVER AT MARSEILLES, IL

MISSISSIPPI RIVER BELOW ALTON, ILL

KASKASKIA RIVER NEAR VENEDY STATION, IL

BIG MUDDY RIVER AT MURPHYSBORO, IL

MISSOURI RIVER AT TOSTON, MT.

MISSOURI RIVER AT VIRGELLE, MT.

MUSSELSHELL RIVER AT MOSBY, MT.

MISSOURI RIVER BELOW FORT PECK DAM, MT.

MILK RIVER AT NASHUA MT

MISSOURI RIVER NEAR CULBERTSON, MT.

YELLOWSTONE RIVER AT BILLINGS MT

BIGHORN RIVER AT BIGHORN, MT.

TONGUE RIVER AT MILES CITY, MT.

POWDER RIVER NEAR LOCATE, MT.

YELLOWSTONE RIVER NEAR SIDNEY, MT.

LITTLE MISSOURI RIVER NR WATFORD CITY, ND

MISSOURI RIVER AT GARRISON DAM, ND

KNIFE RIVER AT HAZEN, ND

CANNONBALL RIVER AT BREIEN, ND

GRAND R AT LITTLE EAGLE SD

BELLE FOURCHE R NEAR ELM SPRINGS SD

CHEYENNE R AT CHERRY CREEK SD

MISSOURI R AT PIERRE SD

WHITE R NEAR OACOMA SD

MISSOURI R AT FORT RANDALL SD

NIOBRARA RIVER NR. VERDEL, IVEBR.

JAMES R NEAR SCOTLAND SD

BIG SIOUX R AT AKRON IA

MISSOURI RIVER AT SIOUX CITY, IOWA

NORTH PLATTE RIVER AT LISCO, NEBR.

SOUTH PLATTE RIVER AT JULESBURG, $C O$.

LOUP $R$ POWER CA AT DIV NR GENOA, NEBR. 
68055.00

68180.00

68566.00

68776.00

68870.00

68923.50

69020.00

69265.10

69345.00

70220.00

70260.00

70320.00

70478.00

70479.00

70778.00

71375.00

71465.00

71579.50

71610.00

71786.20

71935.00

72271.40

72280.00

72315.00

72340.00

72375.00

72450.00

72505.50

72636.20

72654.50

72890.00

72900.00

72925.00

72979.10

73050.00

73085.00

73310.00

73316.00

73555.00

73620.00

73676.40

73695.00

73734.20

73745.25

73785.10

73816.00

73857.00

80159.00

80305.00

80410.00

80665.00

80680.00

80820.00

80982.90
PLATTE R AT LOUISVILLE NE

MISSOURI RIVER AT ST. JOSEPH, MO.

REPUBLICAN R AT CLAY CENTER, KS

SMOKY HILL R AT ENTERPRISE, KS

BIG BLUE $R$ NR MANHATTAN, KS

KANSAS R AT DESOTO, KS

GRAND RIVER NEAR SUMNER MO

OSAGE RIVER BELOW ST. THOMAS, MISSOURI

MISSOURI RIVER AT HERMANN, MO

MISSISSIPPI RIVER AT THEBES ILL

OBION RIVER AT OBION, TENN.

MISSISSIPPI RIVER AT MEMPHIS, TENN.

ST. FRANCIS RIVER AT PARKIN, ARK.

ST. FRANCIS BAY AT RIVERFRONT, ARK.

WHITE RIVER AT CLARENDON, ARK.

ARKANSAS $R$ NR COOLIDGE, KS

ARKANSAS R AT ARKANSAS CITY, KS

CIMARRON RIVER NR BUFFALO, OK

CIMARRON RIVER AT PERKINS, OK

VERDIGRIS RIVER (NEWT GRAHAM L\&D) NEAR INOLA, OK NEOSHO RIVER BLW FT GIBSON LAKE NR FT GIBSON, OK CANADIAN RIVER ABOVE NM-TX STATE LINE, NM

CANADIAN R NR CANADIAN, TX

CANADIIAN RIVER AT CALVIN, OK

BEAVER RIVER AT BEAVER, OK

NORTH CANADIAN RIVER AT WOODWARD, OK

CANADIAN RIVER NR WHITEFIELD, OK

ARKANSAS R. AT DAM NO. 13, NR VAN BUREN, ARK.

ARKANSAS R O DAVID D TERRY L\&D BL LITTLE ROCK AR

MISSISSIPPI RIV NR ARKANSAS CITY, ARK.

MISSISSIPPI RIVER AT VICKSBURG, MS.

BIG BLACK RIVER NR BOVINA, MS.

HOMOCHITTO RIVER AT ROSETTA, MS.

PDTF RED RIVER NEAR WAYSIDE, TEX.

NORTH FORK RED RIVER NR HEADRICK, OK

RED RIVER NR BURKBURNETT, TX

WASHITA RIVER NR DICKSON,OK

RED RIVER AT DENISON DAM NR DENISON, TX

RED R AT ALEXANDRIA

OUACHITA RIVER AT CAMDEN, ARK

OUACHITA RIVER AT COLUMBIA, LA.

TENSAS RIVER AT TENDAL, LOUISIANA

MISSISSIPPI RIVER NEAR ST. FRANCISVILLE, LA

MISSISSIPPI RIVER AT BELLE CHASSE, LA.

AMITE R AT 4H CAMP NR DENHAM SPRINGS

LOWER ATCHAFALAYA RIVER AT MORGAN CITY, LA.

BAYOU TECHE AT KEYSTONE LOCK, NR ST.MARTINVILLE

CALCASIEU R:NR LAKE CHARLES

SABINE RIVER NR RULIFF, TEX.

NECHES RIVER AT EVADALE, TEX.

TRINITY R AT ROMAYOR. TEXAS

WEST FORK SAN JACINTO RIVER NR CONROE, TX

SALT FK BRAZOS R NR ASPERMONT, TX

BRAZOS RIVER NR HIGHBANK, TEX. 


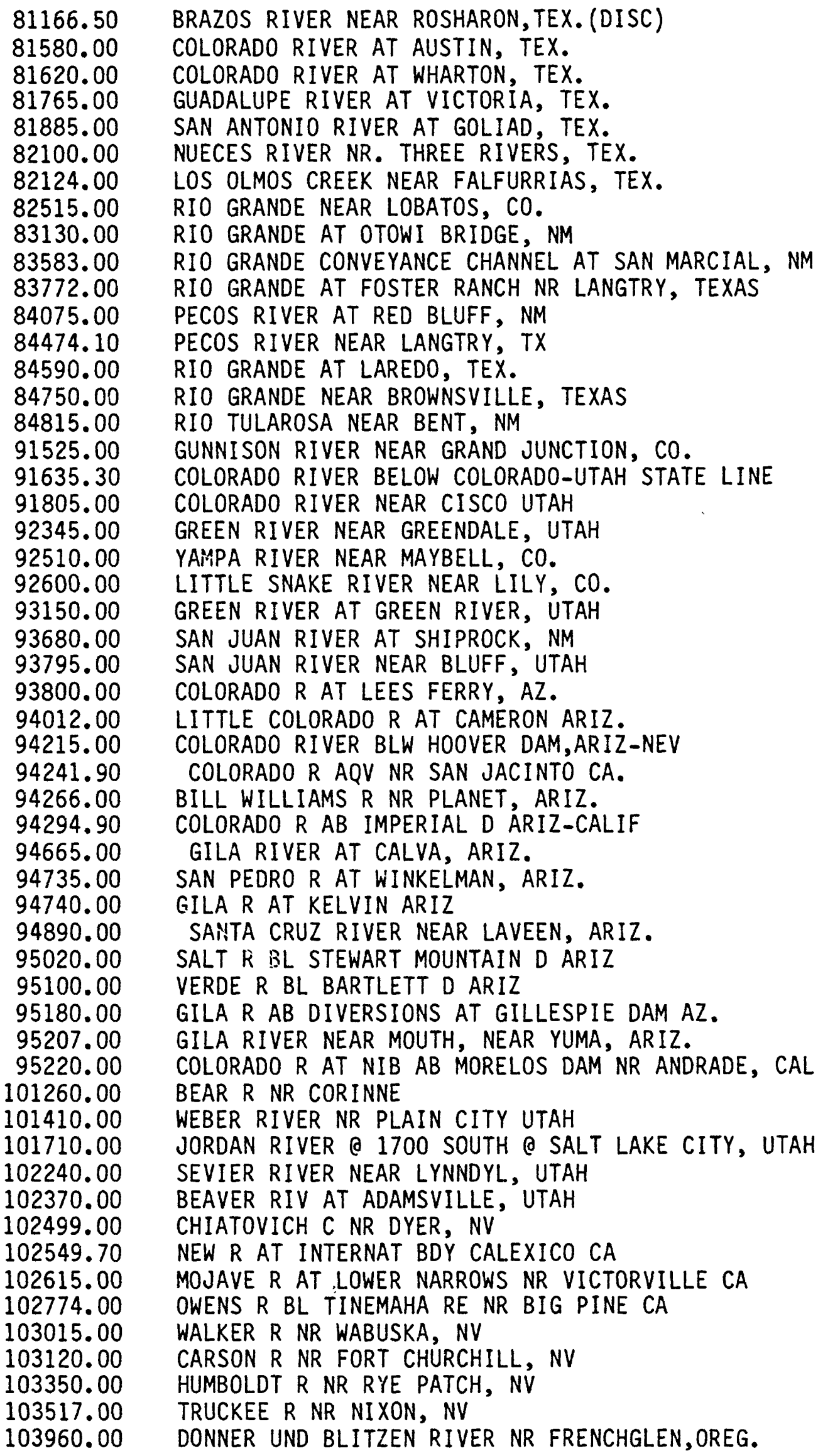


110740.00

111030.10

112500.00

113035.00

113255.00

114476.50

114670.00

115305.00

120310.00

120455.00

122005.00

123185.00

123550.00

123986.00

124005.20

124330.00

125105.00

131545.00

132904.50

133170.00

133532.00

140480.00

141030.00

141130.00

141289.10

142075.00

142117.20

143010.00

143210.00

143723.00

150248.00

152943.50

153040.00

155654.47

157445.00

158960.00

160310.00

162130.00

162293.00

164000.00

166180.00

500381.00

500460.00

500920.00

501440.00
SANTA ANA RIVER BELOW PRADO DAM, CALIF.

LA RIV A WILLOW ST BR A LONG BEACH

FRIANT-KERN CANAL AT FRIANT CALIF

SAN JOAQUIN RIVER NEAR VERNALIS CALIF

MOKELUMNE RIVER AT WOODBRIDGE CALIF

SACRAMENTO RIVER AT FREEPORT CALIF

RUSSIAN RIVER NR GUERNEVILLE CALIF

KLAMATH RIVER NEAR KLAMATH CALIF

CHEHALIS RIVER AT PORTER, WASH.

ELWHA RIVER AT MCDONALD BR NR PRT ANGELES, WASH.

SKAGIT RIVER NEAR MOUNT VERNON, WASH.

KOOTENAI RIVER NR COPELAND, ID

FLATHEAD RIVER AT FLATHEAD, BRITISH COLUMBIA

PEND OREILLE RIVER AT INTERNATIONAL BOUNDARY

COLUMBIA RIVER AT NORTHPORT, WASH.

SPOKANE RIVER AT LONG LAKE, WASH.

YAKIMA RIVER AT KIONA, WASH.

SNAKE RIVER AT KING HILL IDAHO

SNAKE RIVER AT HELLS CANYON DAM ID-OR LINE

SALMON RIVER AT WHITEBIRD, IDAHO

SNAKE RIVER AT BURBANK, WASH.

JOHN DAY R AT MCDONALD FERRY,OREG.

DESCHUTES RIVER AT MOODY, NEAR BIGGS OREG

KLICKITAT RIVER NEAR PITT, WASH.

COLUMBIA RIVER AT WARRENDALE,OREG.

TUALATIN RIVER AT WEST LINN,OREG.

WILLAMETTE RIVER AT PORTLAND,OREG.

NEHALEM RIVER NEAR FOSS, OREG.

UMPQUA RIVER NEAR ELKTON, OREG.

ROGUE RIVER NEAR AGNESS, OREG.

STIKINE $R$ NR WRANGELL AK

SUSITNA RIVER AT SUSITNA STATION AK

KUSKOKWIM RIVER AT CROOKED CREEK AK

YUKON RIVER AT PILOT STATION AK

KOBUK $R$ NR KIANA AK

KUPARUK R NR DEADHORSE AK

WAIMEA RIVER NR WAIMEA, KAUAI, HI

WAIKELE STREAM AT WAIPAHU, OAHU, HI

KALIHI STREAM AT KALIHI, OAHU, HI

HALAWA STREAM NR HALAWA, MOLOKAI, HI

KAHAKULOA STREAM NR HONOKOHAU, MAUI, HI

RIO GRANDE DE MANATI AT HWY 2 NR MANATI, PR

RIO DE LA PLATA AT TOA ALTA, PR

RIO GRANDE DE PATILLAS NR PATILLAS

RIO GRANDE DE ANASCO NR SAN SEBASTIAN, PR 
Table 3. Station list by state.

\begin{tabular}{|c|c|c|}
\hline State & Station No. & National Hydrologic Bench-Mark Stations \\
\hline ALABAMA & 24502.50 & SIPSEY FORK NEAR GRAYSON AL \\
\hline ALASKA & 152927.00 & TALKEETNA RIVER NEAR TALKEETNA AK \\
\hline ARIZONA & 95083.00 & WET BOTTOM CREEK NR CHILDS, ARIZ. \\
\hline ARKANSAS & 70607.10 & NORTH SYLAMORE CREEK NEAR FIFTY SIX, ARK. \\
\hline CALIFORNIA & 114755.60 & ELDER CREEK NEAR BRANSCOMB CALIF \\
\hline CALIFORNIA & 112645.00 & MERCED R AT HAPPY ISLES BRIDGE NR YOSEMITE CALIF \\
\hline COLORADO & 70830.00 & HALFMOON CREEK NEAR MALTA, CO. \\
\hline COLORADO & 93529.00 & VALLECITO CREEK NEAR BAYFIELD, CO. \\
\hline RIDA & 23271.00 & SOPCHOPPY RIVER NR SOPCHOPPY, FLA. \\
\hline RGIA & 22126.00 & FALLING CREEK NEAR JULIETTE, GA. \\
\hline HAWAI I & 167170.00 & HONOLII STREAM NR PAPAIKOU, HAWAII, HI \\
\hline IDAHO & 131695.00 & BIG JACKS CR NR BRUNEAU ID \\
\hline IDAHO & 124160.00 & HAYDEN CK BELOW N FK, NR HAYDEN LAKE, IDAHO \\
\hline INDIANA & 32767.00 & SOUTH HOGAN CREEK NEAR DILLSBORO, IND. \\
\hline IOWA & 79.50 & ELK CREEK NEAR DECATUR CITY, IOWA \\
\hline LOUISIANA & & BIG CREEK AT POLLOCK, LA \\
\hline MAINE & 2.00 & WILD RIVER AT GILEAD, ME \\
\hline MICHIGAN & 40010.00 & WASHINGTON CREEK AT WINDIGO, MICH. \\
\hline MINNESOTA & 51244.80 & KAWISHIWI RIVER NEAR ELY, MN \\
\hline MINNESOTA & 53760.00 & NORTH FORK WHITEWATER RIVER NEAR ELBA, MN \\
\hline MISSISSIPPI & 24791.55 & CYPRESS CREEK NR JANICE, MS \\
\hline MONTANA & 62882.00 & BEAUVAIS CREEK NEAR ST. XAVIER, MT. \\
\hline NEBRASKA & 59.00 & DISMAL RIVER NR THEDFORD NEBR \\
\hline NEVADA & 102493.00 & S TWIN R NR ROUND MOUNTAIN, NV \\
\hline NEVADA & 49.50 & STEPTOE C NR ELY, NV \\
\hline NEW JERSEY & 14665.00 & MCDONALDS B IN LEBANON STATE FOREST NJ \\
\hline NEW MEXICO & 94306.00 & MOGOLLON CREEK NEAR CLIFF, NM \\
\hline NEW MEXICO & 83779.00 & RIO MORA NEAR TERRERO, NM \\
\hline NEW YORK & 13621.98 & ESOPUS CREEK AT SHANDÁKEN, NY \\
\hline NORTH CAROLINA & 34600.00 & CATALOOCHEE CREEK NEAR CATALOOCHEE N C \\
\hline NORTH DAKOTA & 63325.15 & BEAR DEN CREEK NR MANDAREE, ND \\
\hline NORTH DAKOTA & 49.00 & BEAVER CREEK NR FINLEY, ND \\
\hline $\mathrm{OHIO}$ & .80 & UPPER TWIN C AT MCGAW OH \\
\hline OKLAHOMA & 73112.00 & BLUE BEAVER CREEK NR CACHE, OK \\
\hline OKLAHOMA & 73357.00 & KIAMICHI RIVER NR BIG CEDAR, OK \\
\hline OREGON & 114922.00 & CRATER LAKE NEAR CRATER LAKE,OREG. \\
\hline OREGON & .00 & MINAM RIVER AT MINAM,OREG. \\
\hline PENNSYLVANIA & & YOUNG WOMANS CREEK NEAR RENOVO, PA. \\
\hline SOUTH CAROLINA & .00 & SCAPE ORE SWAMP NEAR BISHOPVILLE, SC \\
\hline SOUTH CAROLINA & 219 & UPPER THREE RUNS NEAR NEW ELLENTON, \\
\hline SOUTH DAKOTA & 64090.00 & CASTLE CR ABOVE DEERFIELD RES NEAR HILL CITY SD \\
\hline TENNESSEE & 36040.00 & BUFFALO RIVER NEAR FLAT WOODS, TENN. \\
\hline TEXAS & .00 & LIMPIA CREEK ABOVE FT DAVIS, TEX. \\
\hline TEXAS & & SOUTH FORK ROCKY CREEK NEAR BRIGGS, TEX. \\
\hline UTAH & 101722.00 & RED BUTTE CREEK AT FT. DOUGLAS NR. SLC, UTAH \\
\hline VIRGINIA & 20388.50 & HOLIDAY CREEK NEAR ANDERSONVILLE, VA. \\
\hline WASHINGTON & 124 & ANDREWS CREEK NEAR MAZAMA, WASH. \\
\hline WASHINGTON & 120393.00 & NORTH FORK QUINAULT R NEAR AMANDA PARK, WASH. \\
\hline WISCONSIN & 40637.00 & POPPLE RIVER NEAR FENCE, WI \\
\hline WYOMING & 13018 & CACHE CREEK NEAR JACKSON, WYO. \\
\hline WYOMING & & ENCAMPMENT RIV AB HOG PARK CR NR ENCAMPMENT WYO \\
\hline
\end{tabular}


State

ALABAMA

ALABAMA

ALABAMA

ALABAMA

ALASKA

ALASKA

ALASKA

ALASKA

ALASKA

ALASKA

ARI ZONA

ARIZONA

ARIZONA

ARIZONA

ARIZONA

ARIZONA

ARIZONA

ARIZONA

ARIZONA

ARIZONA

ARIZONA

ARIZONA

ARIZONA

ARKANSAS

ARKANSAS

ARKANSAS

ARKANSAS

ARKANSAS

ARKANSAS

ARKANSAS

BRITISH COLUMB

CALIFORNIA

CALIFORNIA

CALIFORNIA

CALIFORNIA

CALIFORNIA

CALIFORNIA

CALIFORNIA

CALIFORNIA

CALIFORNIA

CALIFORNIA

CALIFORNIA

CALIFORNIA

CALIFORNIA

COLORADO

COLORADO

COLORADO

COLORADO

COLORADO

CONNECTICUT

CONNECTICUT
Station No.

24295.00

24200.00

24490.00

24697.62

157445.00

158960.00

153040.00

150248.00

152943.50

155654.47

94665.00

94890.00

94266.00

93800.00

95220.00

94215.00

95180.00

94740.00

95207.00

94012.00

95020.00

94735.00

95100.00

72654.50

70778.00

72636.20

72505.50

73620.00

70479.00

70478.00

123550.00

94241.90

94294.90

112500.00

115305.00

111030.10

102615.00

113255.00

102549.70

102774.00

114670.00

114476.50

113035.00

110740.00

91525.00

92600.00

82515.00

67640.00

92510.00

11840.00

12055.00
ALABAMA RIVER AT CLAIBORNE AL

ALABAMA RIVER NEAR MONTGOMERY AL

TOMBIGBEE RIVER AT GAINESVILLE, AL

TOMBIGBEE RIVER BL COFFEEVILLE LOCK AND DAM, AL KOBUK R NR KIANA AK

KUPARUK $R$ NR DEADHORSE AK

KUSKOKWIM RIVER AT CROOKED CREEK AK

STIKINE R NR WRANGELL AK

SUSITNA RIVER AT SUSITNA STATION AK

YUKON RIVER AT PILOT STATION AK

GILA RIVER AT CALVA, ARIZ.

SANTA CRUZ RIVER NEAR LAVEEN, ARIZ.

BILL WILLIAMS R NR PLANET, ARIZ.

COLORADO R AT LEES FERRY, AZ.

COLORADO R AT NIB AB MORELOS DAM NR ANDRADE, CA.

COLORADO RIVER BLW HOOVER DAM, ARIZ-NEV

GILA R AB DIVERSIONS AT GILLESPIE DAM AZ.

GILA R AT KELVIN ARIZ

GILA RIVER NEAR MOUTH, NEAR YUMA, AZ.

LITTLE COLORADO R AT CAMERON ARIZ.

SALT R BL STEWART MOUNTAIN D ARIZ

SAN PEDRO R AT WINKELMAN, ARIZ.

VERDE $R$ BL BARTLETT D ARIZ

MISSISSIPPI RIV NR ARKANSAS CITY, ARK.

WHITE RIVER AT CLARENDON, ARK.

ARKANSAS R O DAVID D TERRY L\&D BL LITTLE ROCK AR

ARKANSAS R. AT DAM NO. 13, NR VAN BUREN, ARK.

OUACHITA RIVER AT CAMDEN, ARK

ST. FRANCIS BAY AT RIVERFRONT, ARK.

ST. FRANCIS RIVER AT PARKIN, ARK.

FLATHEAD RIVER AT FLATHEAD, BRITISH COLUMBIA

COLORADO R AQV NR SAN JACINTO CA.

COLORADO RIVER ABOVE IMPERIAL DAM, CA-AZ.

FRIANT-KERN CANAL AT FRIÄIT CALIF

KLAMATH RIVER NEAR KLAMATH CALIF

LA RIV A WILLOW ST BR A LONG BEACH

MOJAVE R AT LOWER NARROWS NR VICTORVILLE CA

MOKELUMNE RIVER AT WOODBRIDGE CALIF

NEW R AT INTERNAT BDY CALEXICO CA

OWENS R BL TINEMAHA RE NR BIG PINE CA

RUSSIAN RIVER NR GUERNEVILLE CALIF

SACRAMENTO RIVER AT FREEPORT CALIF

SAN JOAQUIN RIVER NEAR VERNALIS CALIF

SANTA ANA RIVER BELOW PRADO DAM, CALIF.

GUNNISON RIVER NEAR GRAND JUNCTION, CO.

LITTLE SNAKE RIVER NEAR LILY, CO.

RIO GRANDE NEAR LOBATOS, CO.

SOUTH PLATTE RIVER AT JULESBURG, CO.

YAMPA RIVER NEAR MAYBELL, CO.

CONNECTICUT R AT THOMPSONVILLE, CT

HOUSATONIC R AT STEVENSON, CT 


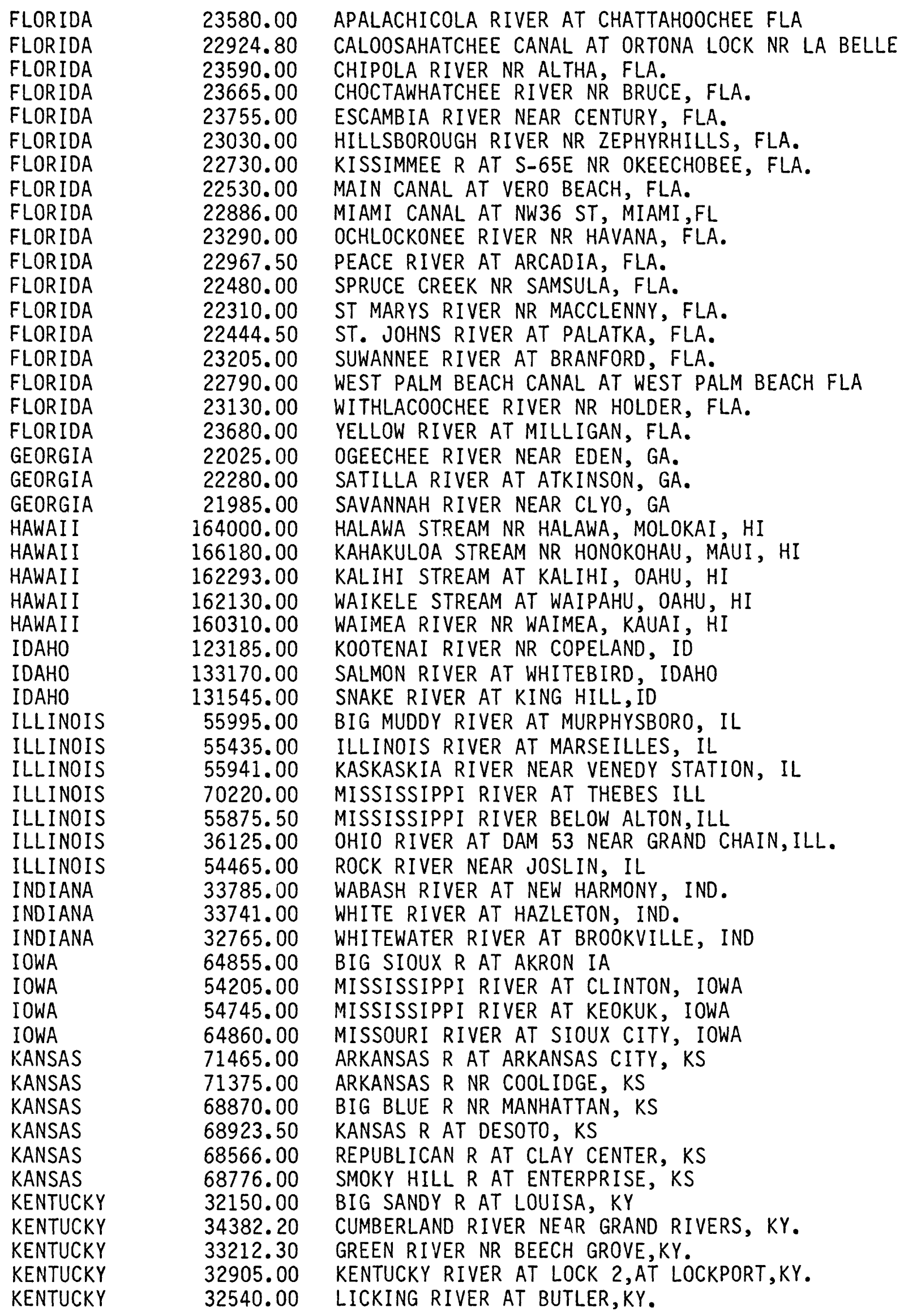




\begin{tabular}{|c|c|c|}
\hline KENTUCKY & 33032.80 & OHIO R AT CANNELTON DAM, KY \\
\hline KENTUCKY & 32166.00 & OHIO R AT GREENUP DAM NR GREENUP, $K Y$ \\
\hline KENTUCKY & 32772.00 & OHIO R AT MARKLAND DAM NR WARSAW, KY \\
\hline KENTUCKY & 33016.30 & ROLLING FORK NR LEBANON JUNCTION,KY. \\
\hline KENTUCKY & 36097.50 & TENNESSEE RIVER AT HIGHWAY 60, NEAR PADUCAH, KY. \\
\hline LOUISIANA & 24920.00 & BOGUE CHITTO NEAR BUSH, LA. \\
\hline LOUISIANA & 73816.00 & LOWER ATCHAFALAYA RIVER AT MORGAN CITY, LA. \\
\hline LOUISIANA & 24895.00 & PEARL RIVER NEAR BOGALUSA, LA. \\
\hline LOUISIANA & 73785.10 & AMITE R AT $4 H$ CAMP NR DENHAM SPRINGS \\
\hline LOUISIANA & 73857.00 & BAYOU TECHE AT KEYSTONE LOCK, NR ST.MARTINVILLE \\
\hline LOUISIANA & 80159.00 & CALCASIEU R NR LAKE CHARLES \\
\hline LOUISIANA & 73745.25 & MISSISSIPPI RIVER AT BELLE CHASSE, LA. \\
\hline LOUISIANA & 73734.20 & MISSISSIPPI RIVER NEAR ST. FRANCISVILLE, LA \\
\hline LOUISIANA & 73676.40 & OUACHITA RIVER AT COLUMBIA, LA. \\
\hline LOUISIANA & 73555.00 & RED R AT ALEXANDRIA \\
\hline LOUISIANA & 73695.00 & TENSAS RIVER AT TENDAL, LOUISIANA \\
\hline MAINE & 10594.00 & ANDROSCOGGIN RIVER AT BRUNSWICK, ME \\
\hline MAINE & 10171.00 & AROOSTOOK RIVER AT CARIBOU, ME \\
\hline MAINE & 10345.00 & PENOBSCOT RIVER AT WEST ENFIELD, ME \\
\hline MAINE & 10660.00 & SÁCO RIVER AT CORNISH, ME \\
\hline MAINE & 10210.50 & ST. CROIX RIVER AT MILLTOWN, ME \\
\hline MARYLAND & 14910.00 & CHOPTANK R NR GREENSBORO, MD \\
\hline MASSACHUSETTS & 11035.00 & CHARLES RIVER AT DOVER, MA \\
\hline MASSACHUSETTS & 1096 & MERRIMACK RIVER ABOVE LOWELL, MA \\
\hline MICHIGAN & 405 & FORD RIVER NR HYDE, MICH. \\
\hline MICHIGAN & 413 & CHEBOYGAN R AT LJNCOLN AVE AT CHEBOYGAN, MICH. \\
\hline MICHIGAN & 41655.00 & CLINTON RIVER AT MOUNT CLEMENS, MICH. \\
\hline MICHIGAN & 41657.00 & DETROIT R AT DETROIT, MICH. \\
\hline MICHIGAN & 40590.00 & ESCANABA RIVER AT CORNELL, MICH. \\
\hline MICHIGAN & 41086.90 & KALAMAZOO RIVER AT SAUGATUCK, MICH. \\
\hline MICHIGAN & 41265.20 & MANISTEE R AT MANISTEE, MICH. \\
\hline MICHIGAN & 40570.04 & MANISTIQUE RIVER ABOVE MANISTIQUE, MICH. \\
\hline MICHIGAN & 41220.30 & MUSKEGON R NR BRIDGETON, MICH. \\
\hline MICHIGAN & 40400.00 & ONTONAGON R NR ROCKLAND, MICH \\
\hline MICHIGAN & 41420.00 & RIFLE PIVER NEAR STERLING, MICH. \\
\hline MICHIGAN & 41570.00 & SAGINAW RIVER AT SAGINAW, MICH. \\
\hline MICHIGAN & 40455.80 & ST MARYS RIVER ABOVE SAULT STE MARIE, MICH. \\
\hline MICHIGAN & 4045 & TAHQUAMENON RIVER NR TAHQUAMENON PARADISE, MICH. \\
\hline MINNESOTA & 4014 & BAPTISM RIVER NEAR EEAVER BAY, MN \\
\hline MINNESOTA & & LITTLE FORK RIVER AT LITTLEFORK, MN \\
\hline MINNESOTA & 53 & MINNESOTA RIVER NEAR JORDAN, MN \\
\hline MINNESOTA & 53 & MISSISSIPPI RIVER AT WINONA, MN \\
\hline MINNESOTA & & MISSISSIPPI RIVER NEAR ROYALTON, MN \\
\hline MINNESOTA & & ROSEAU RIVER BELOW STATE DITCH 51 NR CARIBOU, MN \\
\hline MINNESOTA & 40240 . & ST. LOUIS RIVER AT SCANLON, MN \\
\hline MISSISSIPPI & & BIG BLACK RIVER NR BOVINA, MS \\
\hline MISSISSIPPI & 72925. & HOMOCHITTO RIVER AT ROSETTA, MS \\
\hline MISSISSIPPI & 72890. & MISSISSIPPI RIVER AT VICKSBURG, MS \\
\hline MISSISSIPPI & 24790. & PASCAGOULA RIVER NR BENNDALE, MS \\
\hline MISSOURI & & DES MOINES RIVER AT ST. FRANCISVILLE, MO. \\
\hline MISSOURI & & GRAND RIVER NEAR SUMNER MO \\
\hline MISSOURI & & MISSOURI RIVER AT HERMANN, MO \\
\hline & & MISSOURI RIVER AT ST. JOSEPH, MO. \\
\hline MISSOL & & OSAGE RIVER BELOW ST. THOMAS, MISSOURI \\
\hline
\end{tabular}




\begin{tabular}{|c|c|c|}
\hline MONTANA & 62947.00 & BIGHORN RIVER AT BIGHORN, MT. \\
\hline MONTANA & 61745.00 & MILK RIVER AT NASHUA MT \\
\hline $\begin{array}{l}\text { MONTANA } \\
\text { MONTANA }\end{array}$ & $\begin{array}{l}60545.00 \\
61095.00\end{array}$ & $\begin{array}{ll}\text { MISSOURI } & \text { RIVER AT TOSTON, MT. } \\
\text { MISSOURI RIVER AT VIRGELLE, MT. }\end{array}$ \\
\hline MONTANA & 61320.00 & MISSOURI RIVER BELOW FORT PECK DAM, MT. \\
\hline MONTANA & 61855.00 & MISSOURI RIVER NEAR CULBERTSON, MT. \\
\hline MONTANA & 61305.00 & MUSSELSHELL RIVER AT MOSBY, MT. \\
\hline MONTANA & 63265.00 & POWDER RIVER NEAR LOCATE, MT. \\
\hline MONTANA & 63085.00 & TONGUE RIVER AT MILES CITY, MT. \\
\hline MONTANA & 62145.00 & YELLOWSTONE RIVER AT BILLINGS MT \\
\hline MONTANA & 63295.00 & YELLOWSTONE RIVER NEAR SIDNEY, MT. \\
\hline NEBRASKA & 67924.99 & LOUP $R$ POWER CA AT DIV NR GENOA, NEBR. \\
\hline NEBRASKA & 64655.00 & NIOBRARA RIVER NR. VERDEL, NEBR. \\
\hline NEBRASKA & 66860.00 & NORTH PLATTE RIVER AT LISCO, NEBR. \\
\hline NEBRASKA & 68055.00 & PLATTE R AT LOUISVILLE NE \\
\hline NEVADA & 103120.00 & CARSON R NR FORT CHURCHILL, NV \\
\hline NEVADA & 102499.00 & CHIATOVICH C NR DYER, NV \\
\hline NEVADA & 103350.00 & HUMBOLDT R NR RYE PATCH, NV \\
\hline NEVADA & 103517.00 & TRUCKEE R NR NIXON, NV \\
\hline NEVADA & 103015.00 & WALKER R NR WABUSKA, NV \\
\hline NEW HAMPSHIRE & 11550.50 & CONNECTICUT RIVER AT WALPOLE, NH \\
\hline NEW JERSEY & 14635.00 & DELAWARE R AT TRENTON NJ \\
\hline NEW JERSEY & 14041.00 & RARITAN R NR SOUTH BOUND BROOK NJ \\
\hline NEW JERSEY & 85.00 & TOMS R NR TOMS RIVER NJ \\
\hline NEW MEXICO & 72271.40 & CANADIAN RIVER ABOVE NM-TX STATE LINE, NM \\
\hline NEW MEXICO & 84075.00 & PECOS RIVER AT RED BLUFF, NM \\
\hline NEW MEXICO & 83130.00 & RIO GRANDE AT OTOWI BRIDGE, NM \\
\hline NEW MEXICO & 83583.00 & RIO GRANDE CONVEYANCE CHANNEL AT SAN MARCIAL, NM \\
\hline NEW MEXICO & 84815.00 & RIO TULAROSA NEAR BENT, NM \\
\hline NEW MEXICO & 93680.00 & SAN JUAN RIVER AT SHIPROCK, NM \\
\hline NEW YORK & 42605.00 & BLACK RIVER AT WATERTOWN, NY \\
\hline NEW YORK & 42320.06 & GENESEE RIVER (CHARLOTTE DOCKS)AT ROCHESTER NY \\
\hline NEW YORK & .00 & HUDSON RIVER AT GREEN ISLAND NY \\
\hline NEW YORK & & NIAGARA RIVER (LAKE ONTARIO) AT FORT NIAGARA NY \\
\hline NEW YORK & 42490.00 & OSWEGO RIVER AT LOCK 7 AT OSWEGO NY \\
\hline NEW YORK & 13045 & PECONIC RIVER AT RIVERHEAD NY \\
\hline NEW YORK & 42950.00 & RICHELIEU R (L CHAMPLAIN) AT ROUSES POINT NY \\
\hline NEW YORK & 42643.31 & ST LAWRENCE R AT CORNWALĹ ONT NR MASSENA, NY \\
\hline NEW YORK & 42690.00 & ST REGIS RIVER AT BRASHER CENTER NY \\
\hline NORTH CAROLINA & 21057.69 & CAPE FEAR R AT LOCK \# 1 NR KELLY, NC \\
\hline NORTH CAROLINA & 20895.00 & NEUSE RIVER AT KINSTON, N. C. \\
\hline NORTH CAROLINA & 2129 & PEE DEE R NR ROCKINGHAM, NC \\
\hline NORTH CAROLINA & 2080 & ROANOKE RIVER AT ROANOKE RAPIDS, N.C. \\
\hline NORTH CAROLINA & 20835 & TAR RIVER AT TARBORO, N. C. \\
\hline NORTH DAKOTA & 6354 & CANNONBALL RIVER AT BREIEN, ND \\
\hline NORTH DAKOTA & & KNIFE RIVER AT HAZEN, ND \\
\hline NORTH DAKOTA & 63370.00 & LITTLE MISSOURI RIVER NR WATFORD CITY, ND \\
\hline NORTH DAKOTA & 63384.90 & MISSOURI RIVER AT GARRISON DAM, ND \\
\hline NORTH DAKOTA & & SOURIS RIVER NR WESTHOPE, ND \\
\hline $\mathrm{OHIO}$ & & CUYAHOGA R AT INDEPENDENCE OH \\
\hline $\mathrm{OHIO}$ & 32746.00 & G MIAMI R AT NEW BALTIMORE OH \\
\hline $\mathrm{OHIO}$ & 324 & L MIAMI R AT MILFORD OH \\
\hline $\mathrm{OHIO}$ & & MAUMEE R AT WATERVILLE OH \\
\hline $\mathrm{OHIO}$ & 3150 & MUSKINGUM R AT MCCONNELSVILLE OH \\
\hline
\end{tabular}


OHIO

OKLAHOMA

OKLAHOMA

OKLAHOMA

OKLAHOMA

OKLAHOMA

OKLAHOMA

OKLAHOMA

OKLAHOMA

OKLAHOMA

OKLAHOMA

OREGON

OREGON

OREGON

OREGON

OREGON

OREGON

OREGON

OREGON

OREGON

OREGON

PENNSYLVANIA

PENNSYLVANIA

PENNSYLVANIA

PENNSYLVANIA

PENNSYLVANIA

PENNSYLVANIA

PUERTO RICO

PUERTO RICO

PUERTO RICO

PUERTO RICO

SOUTH CAROLINA

SOUTH CAROLINA

SOUTH CAROLINA

SOUTH CAROLINA

SOUTH CAROLINA

SOUTH DAKOTA

SOUTH DAKOTA

SOUTH DAKOTA

SOUTH DAKOTA

SOUTH DAKOTA

SOUTH DAKOTA

SOUTH DAKOTA

TENNESSEE

TENNESSEE

TENNESSEE

TENNESSEE

TENNESSEE

TENNESSEE

TENNESSEE

TEXAS

TEXAS

TEXAS

TEXAS
32345.00

72340.00

72315.00

72450.00

71610.00

71579.50

71935.00

72375.00

73050.00

71786.20

73310.00

141289.10

141030.00

103960.00

140480.00

143010.00

143723.00

132904.50

142075.00

143210.00

142117.20

30496.25

30850.00

14745.00

15405.00

15705.00

15535.00

500460.00

501440.00

500381.00

500920.00

21360.00

21765.00

21750.00

21705.00

21320.00

64380.00

64393.00

63578.00

64785.00

64530.00

64400.00

64520.00

34250.00

34705.00

70320.00

70260.00

35930.05

35718.50

35430.05

81166.50

80982.90

72280.00

81580.00
SCIOTO R AT HIGBY OH

BEAVER RIVER AT BEAVER, OK

CANADIAN RIVER AT CALVIN, OK

CANADIAN RIVER NR WHITEFIELD, OK

CIMARRON RIVER AT PERKINS, OK

CIMARRON RIVER NR BUFFALO, OK

NEOSHO RIVER BLW FT GIBSON LAKE NR FT GIBSON, OK

NORTH CANADIAN RIVER AT WOODWARD, OK

NORTH FORK RED RIVER NR HEADRICK, OK

VERDIGRIS RIVER (NEWT GRAHAM L\&D) NEAR INOLA, OK

WASHITA RIVER NR DICKSON,OK

COLUMBIA RIVER AT WARRENDALE, OREG.

DESCHUTES RIVER AT MOODY, NEAR BIGGS OREG

DONNER UND BLITZEN RIVER NR FRENCHGLEN,OREG.

JOHN DAY R AT MCDONALD FERRY,OREG.

NEHALEM RIVER NEAR FOSS, OREG.

ROGUE RIVER NEAR AGNESS,OREG.

SNAKE RIVER AT HELLS CANYON DAM ID-OR LINE

TUALATIN RIVER AT WEST LINN,OREG.

UMPQUA RIVER NEAR ELKTON, OREG.

WILLAMETTE RIVER AT PORTLAND,OREG.

ALLEGHENY R AT NEW KENSINGTON, PA.

MONONGAHELA RIVER AT BRADDOCK, PA.

SCHUYLKILL RIVER AT PHILADELPHIA, PA.

SUSQUEHANNA RIVER AT DANVILLE, PA.

SUSQUEHANNA RIVER AT HARRISBURG, PA.

WEST BRANCH SUSQUEHANNA RIVER AT LEWISBURG, PA.

RIO DE LA PLATA AT TOA ALTA, PR

RIO GRANDE DE ANASCO NR SAN SEBASTIAN, PR

RIO GRANDE DE MANATI AT HWY 2 NR MANATI, PR

RIO GRANDE DE PATILLAS NR PATILLAS

BLACK RIVER AT KINGSTREE, S.C.

COOSAWHATCHIE RIVER NR HAMPTON S.C.

EDISTO RIVER NR GIVHANS S.C.

LAKES M-M DIV CANAL NR PINEVILLE S. C.

LYNCHES RIVER AT EFFINGHAM S. C.

BELLE FOURCHE R NEAR ELM SPRINGS SD

CHEYENNE R AT CHERRY CREEK SD

GRAND R AT LITTLE EAGLE SD

JAMES R NEAR SCOTLAND SD

MISSOURI R AT FORT RANDALL SD

MISSOURI R AT PIERRE SD

WHITE R NEAR OACOMA SD

CUMBERLAND RIVER AT CARTHAGE, TENN.

FRENCH BROAD RIVER NEAR KNOXVILLE, TENN.

MISSISSIPPI RIVER AT MEMPHIS, TENN.

OBION RIVER AT OBION, TENN.

TENNESSEE RIVER AT PICKWICK LANDING DAM (LL), TN

TENNESSEE RIVER AT SOUTH PITTSBURG, TENN.

TENNESSEE RIVER AT WATTS BAR DAM (TAILWATER), TN

BRAZOS RIVER NEAR ROSHARON, TEX. (DISC)

BRAZOS RIVER NR HIGHBANK, TEX.

CANADIAN R NR CANADIAN, TX

COLORADO RIVER AT AUSTIN, TEX. 


\begin{tabular}{|c|c|c|}
\hline TEXAS & 81620.00 & COLORADO RIVER AT WHARTON, TEX. \\
\hline TEXAS & 81765.00 & GUADALUPE RIVER AT VICTORIA, TEX. \\
\hline TEXAS & 82124.00 & LOS OLMOS CREEK NEAR FALFURRIAS, TEX. \\
\hline TEXAS & 80410.00 & NECHES RIVER AT EVADALE, TEX. \\
\hline TEXAS & 82100.00 & NUECES RIVER NR. THREE RIVERS, TEX. \\
\hline TEXAS & 72979.10 & PDTF RED RIVER NEAR WAYSIDE, TEX. \\
\hline TEXAS & 84474.10 & PECOS RIVER NEAR LANGTRY, TX \\
\hline TEXAS & 73316.00 & RED RIVER AT DENISON DAM NR DENISON, TX \\
\hline TEXAS & 73085.00 & RED RIVER NR BURKBURNETT, TX \\
\hline TEXAS & 83772.00 & RIO GRANDE AT FOSTER RANCH NR LANGTRY, TEXAS \\
\hline TEXI & 84590.00 & RIO GRANDE AT LAREDO, TEX. \\
\hline TEXAS & 84750.00 & RIO GRANDE NEAR BROWNSVILLE, TEXAS \\
\hline TEXAS & 80305.00 & SAB!NE RIVER NR RULIFF, TEX. \\
\hline TEXAS & 80820.00 & SAL: FK BRAZOS R NR ASPERMONT, TX \\
\hline TEXAS & 81885.00 & SAN ANTONIO RIVER AT GOLIAD, TEX. \\
\hline TEXAS & 80665.00 & TRINITY R AT ROMAYOR, TEXAS \\
\hline TEXAS & 80680.00 & WEST FORK SAN JACINTO RIVER NR CONROE, TX \\
\hline UTAH & 101260.00 & BEAR R NR CORINNE \\
\hline UTAH & 102370.00 & BEAVER RIV AT ADAMSVILLE, UTAH \\
\hline UTAH & 91635.30 & COLORADO RIVER BELOW COLORADO-UTAH STATE LINE \\
\hline UTAH & 91805.00 & COLORADO RIVER NEAR CISCO UTAH \\
\hline UTAH & 93150.00 & GREEN RIVER AT GREEN RIVER, UTAH \\
\hline UTAH & 92345.00 & GREEN RIVER NEAR GREENDALE, UTAH \\
\hline UTAH & 101710.00 & JORDAN RIVER \& 1700 SOUTH \& SALT LAKE CITY, UTAH \\
\hline UTAH & 93795.00 & SAN JUAN RIVER NEAR BLUFF, UTAH \\
\hline UTAH & 102240.00 & SEVIER RIVER NEAR LYNNDYL, UTAH \\
\hline UTAH & 101410.00 & WEBER RIVER NR PLAIN CITY UTAH \\
\hline VIRGINIA & 16730.00 & PAMUNKEY RIVER NR HANOVER VA \\
\hline VIRGINIA & 20495.00 & BLACKWATER R NR FRANKLIN, VA \\
\hline VIRGINIA & 20350.00 & JAMES RIVER AT CARTERSVILLE, VA \\
\hline VIRGINIA & 16465.80 & POTOMAC R AT CHAIN BRIDGE, AT WASH, DC \\
\hline WASHINGTON & 120310.00 & CHEHALIS RIVER AT PORTER, WASH. \\
\hline WASHINGTON & 124005.20 & COLUMBIA RIVER AT NORTHPORT, WASH. \\
\hline WASHINGTON & 120455.00 & ELWHA RIVER AT MCDONALD BR NR PRT ANGELES, WASH. \\
\hline WASHINGTON & 141130.00 & KLICKITAT RIVER NEAR PITT, WASH. \\
\hline WASHINGTON & 123986.00 & PEND OREILLE RIVER AT INTERNATIONAL BOUNDARY \\
\hline WASHINGTON & 122005.00 & SKAGIT RIVER NEAR MOUNT VERNON, WASH. \\
\hline WASHINGTON & 133532.00 & SNAKE RIVER AT BURBANK, WASH. \\
\hline WASHINGTON & 124330.00 & SPOKANE RIVER AT LONG LAKE, WASH. \\
\hline WASHINGTON & 125105.00 & YAKIMA RIVER AT RIONA, WASH. \\
\hline WEST VIRGINIA & 32013.00 & KANAWHA RIVER AT WINFIELD, WV \\
\hline WISCONSIN & 53695.00 & CHIPPEWA RIVER AT DURAND, WI \\
\hline WISCONSIN & 40850.00 & FOX RIVER AT WRIGHTSTOWN, WI \\
\hline WISCONSIN & 40870.00 & MILWAUKEE RIVER AT MILWAUKEE, WI \\
\hline WISCONSIN & 53405.00 & ST. CROIX RIVER AT ST. CROIX FALLS, WI \\
\hline WISCONSIN & 54070.00 & WISCONSIN RIVER AT MUSCODA, WI \\
\hline
\end{tabular}


Summary Tables for the Bench-Mark and NASQAN stations listed in Table 2 and Table 3 are available on request from the National Water Data Exchange, U.S. Geological Survey, Reston, Virginia, 22092, telephone (703) 860-6031. Tables are available through the mail or by wire to remote terminal. An example table for station no. 11035.00, Charles River at Dover, MA appears on the following page. 
Statistical summary by station (example)

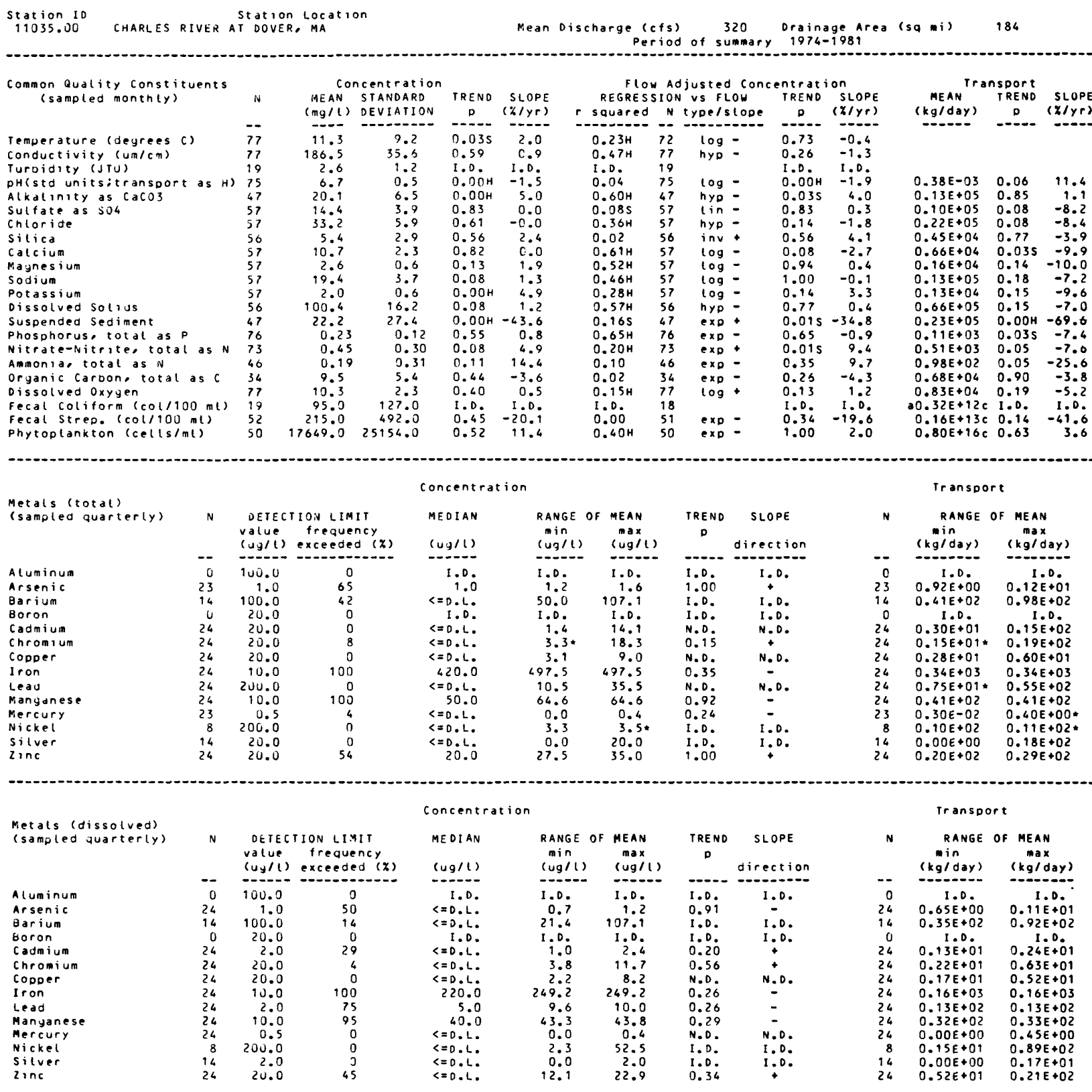

Notes

Detection $(i m)$ ts refer to the highest laboratory detection limits used during the period of record. Consequently, estimated mean metal concentrations may be lower than the stated detection limits.

-a' denotes transport rates estimated as averages of monthly or quarterly sample data. otheruise daily flow frequency distributions are used in the estimation of transport rates (see text).

' $c$ ' denotes transport rates expressed as colonies per day (bacteria) or cells per day (phytoplankton).

** tenotes mean total metal concentrations estimated as less than the corresponding mean dissolved metal concentrations.

Abbreviations

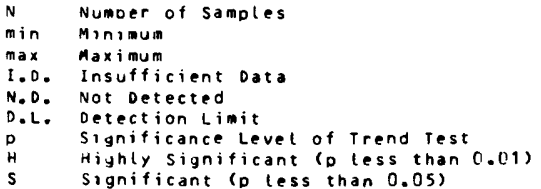

cfs Cubic feet per second
c celsius
JTu Jackson Turbidity Units
col Colonies
lin Linear
log Log
hyp Hyperbolic
inv Inverse
exp Exponential




\section{References}

Aitchison, J., and Brown, J. A. C., 1963, the Lognormal Distribution: Cambridge at the University Press.

Cobb, E. D., and Biesecker, J. E., 1971, The National Hydrologic BenchMark Network: U.S. Geological Survey Circular 460-D, 38p.

Fenneman, N. M., 1928, Physiographic Divisions of the United States, 3d ed., revised and enlarged: Assoc. Am. Geographers Annals, v. 18, No. 4, p. $261-353$.

Ficke, J. F., and Hawkinson, R. 0., 1975, The National Stream Quality Accounting Network (NASQAN)--some questions and answers; U.S. Geological Survey Circular $719,23 \mathrm{p}$.

Heien, D. M., 1968, A note on log-linear regression: J. of the Am. Stat. Assoc., V. 63, No. 323, p. 1034.

Hirsch, R. M., Slack, J. R., and Smith, R. A., 1982, Techniques of trend analys is for monthly water-quality data: Water Resources Research, v. 18 , no. 1, p. 107-121.

Hutchison, N. E., and others, 1975, WATSTORE user's guide: U.S. Geological Survey Open-File Report $75-426, v$. I and III.

Langbein, W. B., and Hoyt, W. G., 1959, Water facts for the nation's future: New York, Ronald Press Co., 288 p.

Leopold, L. B., 1962, A national network of hydrologic bench marks: U.S. Geological Survey Circular 460-B, 4 p.

Searcy, J. K., 1959, Flow duration curves: U.S. Geological Survey Water Supply Paper 1542-A, $33 \mathrm{p}$.

Skougstad, M. W., and others [eds.], 1979, Methods for determination of inorganic substances in water and fluvial sediments: Techniques of Water-Resources Investigations of the United States Geological Survey, Book 5, Chapter A-1, 626 p.

Smith, R. A., Hirsch, R. M., and Slack, J. R., 1982, A study of trends in total phosphorus measurements at NASQAN stations: U.S. Geological Survey Water-Supply Paper 2190, $34 \mathrm{p}$. 